\title{
Structural Mapping and Framework Interconversions in 1D, 2D, and 3D Divalent Metal R,S-Hydroxyphosphonoacetate Hybrids
}

\author{
Rosario M. P. Colodrero, ${ }^{\dagger}$ Pascual Olivera-Pastor,${ }^{\dagger}$ Aurelio Cabeza, ${ }^{\dagger}$ Maria Papadaki, ${ }^{\ddagger}$ \\ Konstantinos D. Demadis, ${ }^{, \neq}$and Miguel A. G. Aranda*, \\ †Departamento de Química Inorgánica, Universidad de Málaga, Campus Teatinos S/N. 29071-Málaga, Spain \\ and ${ }^{\star C}$ Crystal Engineering, Growth and Design Laboratory, Department of Chemistry, University of Crete, \\ Voutes Campus, Crete GR-71003, Greece
}

Received October 17, 2009

\begin{abstract}
Reactions of divalent cations $\left(\mathrm{Mg}^{2+}, \mathrm{Co}^{2+}, \mathrm{Ni}^{2+}\right.$, and $\left.\mathrm{Zn}^{2+}\right)$ with $R$,S-hydroxyphosphonoacetic acid (HPAA) in aqueous solutions ( $\mathrm{pH}$ values ranging 1.0-4.0) yielded a range of crystalline hydrated M-HPAA hybrids. Onedimensional (1D) chain compounds were formed at room temperature whereas reactions conducted under hydrothermal conditions resulted in two-dimensional (2D) layered frameworks or, in some cases, three-dimensional (3D) networks incorporating various alkaline cations. $1 \mathrm{D}$ phases with compositions $\left[\mathrm{M}\left\{\mathrm{HO}_{3} \mathrm{PCH}(\mathrm{OH}) \mathrm{CO}_{2}\right\}\left(\mathrm{H}_{2} \mathrm{O}\right)_{2}\right]$. $2 \mathrm{H}_{2} \mathrm{O}(\mathrm{M}=\mathrm{Mg}, \mathrm{Co}$, and $\mathrm{Zn})$ were isolated. These compounds were dehydrated in liquid water to yield the corresponding $\left[\mathrm{M}\left\{\mathrm{HO}_{3} \mathrm{PCH}(\mathrm{OH}) \mathrm{CO}_{2}\right\}\left(\mathrm{H}_{2} \mathrm{O}\right)_{2}\right]$ compounds lacking the lattice water between the $1 \mathrm{D}$ chains. $\left[\mathrm{M}\left\{\mathrm{HO}_{3} \mathrm{PCH}(\mathrm{OH}) \mathrm{CO}_{2}\right\}\left(\mathrm{H}_{2} \mathrm{O}\right)_{2}\right](\mathrm{M}=\mathrm{Mg}, \mathrm{Ni}, \mathrm{Co}, \mathrm{Zn})$ compounds were formed by crystallization at room temperature (at higher $\mathrm{pH}$ values) or also by partial dehydration of $1 \mathrm{D}$ compounds with higher hydration degrees. Complete dehydration of these $1 \mathrm{D}$ solids at $240-270^{\circ} \mathrm{C}$ led to $3 \mathrm{D}$ phases, $\left[\mathrm{M}\left\{\mathrm{HO} 3 \mathrm{PCH}(\mathrm{OH}) \mathrm{CO}_{2}\right\}\right]$. The $2 \mathrm{D}$ layered compound $\left[\mathrm{Mg}\left\{\mathrm{HO}_{3} \mathrm{PCH}(\mathrm{OH}) \mathrm{CO}_{2}\right\}\left(\mathrm{H}_{2} \mathrm{O}\right)_{2}\right]$ was obtained under hydrothermal conditions. For both synthesis methods, addition of alkali metal hydroxides to adjust the $\mathrm{pH}$ usually led to mixed phase materials, whereas direct reactions between the metal oxides and the hydroxyphosphonoacetic acid gave single phase materials. On the other hand, adjusting the $\mathrm{pH}$ with acetate salts and increasing the ratio $\mathrm{M}^{2+} / \mathrm{HPAA}$ and/or the $\mathrm{A}^{+} / \mathrm{M}^{2+}$ ratio $(A=\mathrm{Na}, \mathrm{K})$ resulted in $3 \mathrm{D}$ networks, where the alkali cations were incorporated within the frameworks for charge compensation. The crystal structures of eight new M(II)-HPAA hybrids are reported herein and the thermal behavior related to dehydration/rehydration of some compounds are studied in detail.
\end{abstract}

\section{Introduction}

Recently, significant attention has been drawn to the use of polyfunctional phosphonic acids as ligands to obtain new versatile metal phosphonate compounds for potential applications in diverse fields. ${ }^{1-4}$ By fine-tuning the synthesis conditions, self-assembly processes involving these multidentate ligands and metal ions result in diverse coordination polymers with $1-, 2-$, or $3 \mathrm{D}$ supramolecular networks. ${ }^{4,5}$ Among the polyfunctional ligands $R, S$-hydroxyphophonoacetic acid (HPAA) is a promising

*To whom correspondence should be addressed. E-mail: g_aranda@ uma.es (M.A.G.A.), demadis@chemistry.uoc.gr (K.D.D.).

(1) Stock, N.; Bein, T. Angew. Chem., Int. Ed. 2004, 43, 749-752.

(2) Clearfield, A. Dalton Trans. 2008, 6089-6102.

(3) Miller, S. R.; Pearce, G. M.; Wright, P. A.; Bonino, F.; Chavan, S.; Bordiga, S.; Margiolaki, I.; Guillou, N.; Férey, G.; Bourrelly, S.; Llewellyn, P. L. J. Am. Chem. Soc. 2008, 130, 15967-15981.

(4) (a) Demadis, K. D.; Papadaki, M.; Raptis, R. G.; Zhao, H. Chem. Mater. 2008, 20, 4835-4846. (b) Demadis, K. D.; Papadaki, M.; Raptis, R. G.; Zhao, H. J. Solid State Chem. 2008, 181, 679-683.

(5) Stock, N.; Bein, T. J. Mater. Chem. 2005, 15, 1384-1391.

(6) Dong, D.; Li, J.; Sun, Z.; Zheng, X.; Chen, H.; Meng, L.; Zhu, Y.; Zhao, Y.; Zhang, J. Inorg. Chem. Commun. 2007, 10, 1109-1112. candidate, ${ }^{6}$ because it is a simple low molecular weight species bearing three different coordination groups $\left(-\mathrm{OH},-\mathrm{COOH}\right.$ and $\left.-\mathrm{PO}_{3} \mathrm{H}_{2}\right)$. HPAA is also chemically stable, cost-effective, and safe to use, with demonstrated applications as corrosion inhibitor. ${ }^{4}$ Moreover, the presence of a chiral carbon in its backbone opens the possibility to synthesize noncentrosymmetric metalorganic coordination polymers for possible nonlinear optical applications. ${ }^{7}$

(7) Fu, R.; Zhang, H.; Wang, L.; Hu, S.; Li, Y.; Huang, X.; Wu, X. Eur. J. Inorg. Chem. 2005, 3211-3213.

(8) (a) Li, J.; Dong, D.; Huang, C.; Sun, Z.; Zhu, Y. Acta Crystallogr. 2007, E63, 2348-2349. (b) Lodhia, S.; Turner, A.; Papadaki, M.; Demadis, K. D.; Hix, G. B. Cryst. Growth Des. 2009, 9, 1811-1822. (c) Demadis, K. D.; Papadaki, M.; Aranda, M. A. G.; Cabeza, A.; Oliveira-Pastor, P.; Sanakis, Y. Cryst. Growth Des. 2010, in press, DOI: 10.1021/cg900943x.

(9) (a) Fu, R.; Xiang, S.; Zhang, H.; Zhang, J.; Wu, X. Cryst. Growth Des. 2005, 5, 1795-1799. (b) Zhang, Y.-Y.; Zeng, M.-H.; Qi, Y.; Sang, S.-Y.; Liu, Z.-M. Inorg. Chem. Commun. 2007, 10, 33-36. (c) Sun, Z.; Chen, H.; Liu, Z.; Cui, L.; Zhu, Y.; Zhao, Y.; Zhang, J.; You, W.; Zhu, Z. Inorg. Chem. Commun. 2007, 10, 283-286. (d) Cui, L.; Sun, Z.; Chen, H.; Meng, L.; Dong, D.; Tian, C.; Zhu, Z.; You, W. J. Coord. Chem. 2007, 60, 1247-1254. 
Table 1. Overview of Reported/Synthesized Metal(II) Hydroxyphosphonoacetate Hybrid Materials with Metal:Ligand Molar Ratio 1:1

\begin{tabular}{|c|c|c|}
\hline phase/stoichiometry & acronyms $^{a}$ & reference \\
\hline$\left[\mathrm{M}\left\{\mathrm{HO}_{3} \mathrm{PCH}(\mathrm{OH}) \mathrm{CO}_{2}\right\}\left(\mathrm{H}_{2} \mathrm{O}\right)_{2}\right] \cdot 2 \mathrm{H}_{2} \mathrm{O}$ & M-L-2-2-1D & $\mathrm{M}=\mathrm{Mg}, \mathrm{Co}, \mathrm{Zn}$ (this work) \\
\hline$\left[\mathrm{M}\left\{\mathrm{HO}_{3} \mathrm{PCH}(\mathrm{OH}) \mathrm{CO}_{2}\right\}\left(\mathrm{H}_{2} \mathrm{O}\right)_{2}\right] \mathrm{H}_{2} \mathrm{O}$ & M-L-2-1-1D & $\mathrm{M}=\mathrm{Cu} ;{ }^{8 \mathrm{~b}} \mathrm{Ni}$ (this work) \\
\hline$\left[\mathrm{M}\left\{\mathrm{HO}_{3} \mathrm{PCH}(\mathrm{OH}) \mathrm{CO}_{2}\right\}\left(\mathrm{H}_{2} \mathrm{O}\right)_{2}\right]$ & M-L-2-0-1D & $\mathrm{M}=\mathrm{Ni} ;{ }^{\mathrm{a} a} \mathrm{Cu} ;{ }^{8 \mathrm{c}} \mathrm{Mg}, \mathrm{Co}, \mathrm{Zn}$ (this work) \\
\hline$\left[\mathrm{Sr}\left\{\mathrm{HO}_{3} \mathrm{PCH}(\mathrm{OH}) \mathrm{CO}_{2}\right\}\left(\mathrm{H}_{2} \mathrm{O}\right)_{3}\right] \mathrm{H}_{2} \mathrm{O}$ & Sr-L-3-1-2D & [4] \\
\hline$\left[\mathrm{M}\left\{\mathrm{HO}_{3} \mathrm{PCH}(\mathrm{OH}) \mathrm{CO}_{2}\right\}\left(\mathrm{H}_{2} \mathrm{O}\right)_{2}\right]$ & M-L-2-0-2D & $\mathrm{M}=\mathrm{Fe}, \mathrm{Mn}, \mathrm{Co}, \mathrm{Zn} ;{ }^{9 \mathrm{a}} \mathrm{Mg}$ (this work) \\
\hline $\mathrm{Na}_{2}\left[\mathrm{Cd}_{2}\left\{\mathrm{O}_{3} \mathrm{PCH}(\mathrm{OH}) \mathrm{CO}_{2}\right\}_{2}\left(\mathrm{H}_{2} \mathrm{O}\right)_{3}\right] \cdot 2 \mathrm{H}_{2} \mathrm{O}$ & CdNa-L-1.5-1-2D & 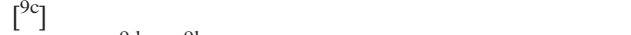 \\
\hline$\left[\mathrm{enH}_{2}\right]\left[\mathrm{M}_{2}\left\{\mathrm{O}_{3} \mathrm{PCH}(\mathrm{OH}) \mathrm{CO}_{2}\right\}_{2}\left(\mathrm{H}_{2} \mathrm{O}\right)_{2}\right] \cdot 2 \mathrm{H}_{2} \mathrm{O}$ & $\mathrm{M}\left[\mathrm{enH}_{2}\right]_{0.5}-\mathrm{L}-1-1-2 \mathrm{D}$ & $\mathrm{M}=\mathrm{Fe} ;{ }^{9 \mathrm{~d}} \mathrm{Co}^{9 \mathrm{~b}}$ \\
\hline$\left[\mathrm{M}\left\{\mathrm{HO}_{3} \mathrm{PCH}(\mathrm{OH}) \mathrm{CO}_{2}\right\}\left(\mathrm{H}_{2} \mathrm{O}\right)_{2}\right]$ & M-L-2-0-3D & $\mathrm{M}=\mathrm{Sr} ; \mathrm{Ba}^{4 \mathrm{a}, \mathrm{b}}$ \\
\hline$\left[\mathrm{M}\left\{\mathrm{HO}_{3} \mathrm{PCH}(\mathrm{OH}) \mathrm{CO}_{2}\right\}\right]$ & M-L-0-0-3D & $\mathrm{M}=\mathrm{Cu} ;{ }^{8 \mathrm{c}} \mathrm{Mg}, \mathrm{Co}, \mathrm{Ni}, \mathrm{Zn}$ (this work) \\
\hline$\left[\mathrm{NaM}\left\{\mathrm{O}_{3} \mathrm{PCH}(\mathrm{OH}) \mathrm{CO}_{2}\right\}\right]$ & MNa-L-0-0-3D & $\mathrm{M}=\mathrm{Co} ;{ }^{10 \mathrm{a}, \mathrm{b}} \mathrm{Mn} ;{ }^{10 \mathrm{a}, \mathrm{b}} \mathrm{Fe} ;{ }^{10 \mathrm{a}, \mathrm{c}} \mathrm{Zn} ;{ }^{10 \mathrm{a}} \mathrm{Mg}$ (this work) \\
\hline$\left[\mathrm{AZn}\left\{\mathrm{O}_{3} \mathrm{PCH}(\mathrm{OH}) \mathrm{CO}_{2}\right\}\right]$ & ZnA-L-0-0-3D & $\mathrm{A}=\mathrm{NH}_{4}^{+} ; \mathrm{K}^{+}$(this work) \\
\hline$\left[\mathrm{Mg}_{0.5} \mathrm{Cd}\left\{\mathrm{O}_{3} \mathrm{PCH}(\mathrm{OH}) \mathrm{CO}_{2}\right\}\right]$ & $\mathrm{CdMg}_{0.5}-\mathrm{L}-0-0-3 \mathrm{D}$ & {$\left[{ }^{10 \mathrm{~d}}\right]$} \\
\hline
\end{tabular}

${ }^{a}$ The acronym M(A)-L-x-y-nD is followed throughout the manuscript, where $\mathbf{M}$ is the divalent cation; $\mathbf{A}$ is a charge-compensating cation (present in some cases); $\mathbf{L}$ is the HPAA ligand, $\mathbf{x}$ is the number of M-bound water molecules, $\mathbf{y}$ is the number of lattice water molecules, and $\mathbf{n}$ is the dimensionality of the framework.

Yet, rational design of the synthesis of metal phosphonates, $\mathrm{M}^{n+}$-HPAA, is not an easy task because of a large number of experimental factors that must be precisely controlled. One-dimensional (1D) ${ }^{8}$ two-dimensional (2D), ${ }^{4,9}$ and three-dimensional $(3 \mathrm{D})^{4,8 c, 10,11}$ materials based on the HPAA ligand have been reported. Generally, reactions of hydrated metal salts and HPAA at low pH (ca. 2-3) and room temperature (RT) yield 1D materials. ${ }^{8}$ Under these conditions, the ligand and $\mathrm{M}^{2+}$ are believed to have the same number of charges but with opposite sign, resulting in neutral frameworks with 1:1 metal/ligand molar ratio. Obtaining single phase products may be sometimes difficult, likely because of the coexistence of phases with variable number of water molecules of crystallization. ${ }^{4,8 b}$

On the other hand, hydrothermal reactions usually lead to higher dimensionality solids. For instance, an isostructural series is known, $\left[\mathrm{M}\left\{\mathrm{HO}_{3} \mathrm{PCH}(\mathrm{OH}) \mathrm{CO}_{2}\right\}\left(\mathrm{H}_{2} \mathrm{O}\right)_{2}\right](\mathrm{M}=\mathrm{Mn}$, $\mathrm{Fe}, \mathrm{Co}$, and $\mathrm{Zn}$ ), whose members have a layered structure. ${ }^{9 \mathrm{a}}$ The presence of additional cation species usually leads to 3D structures. A number of M(II)-HPAA frameworks of this type are known, namely, $\left.\left[\left(\mathrm{NH}_{4}\right) \mathrm{Zn}\left\{\mathrm{O}_{3} \mathrm{PCH}(\mathrm{OH}) \mathrm{CO}_{2}\right\}\right]\right]^{7}$ $\left[\mathrm{Na}_{2} \mathrm{Cd}_{2}\left\{\mathrm{O}_{3} \mathrm{PCH}(\mathrm{OH}) \mathrm{CO}_{2}\right\}_{2}\left(\mathrm{H}_{2} \mathrm{O}\right)_{3}\right] \cdot 2 \mathrm{H}_{2} \mathrm{O},{ }^{9 \mathrm{c}} \quad \mathrm{Mg}_{0.5} \mathrm{Cd}\left\{\mathrm{O}_{3^{-}}\right.$ $\left.\left.\mathrm{PCH}(\mathrm{OH}) \mathrm{CO}_{2}\right\},{ }^{10 \mathrm{~d}}\left[\left(\mathrm{enH}_{2}\right)_{0.5} \mathrm{Co}_{2} \mathrm{O}_{3} \mathrm{PCH}(\mathrm{OH}) \mathrm{CO}_{2}\right\}\left(\mathrm{H}_{2} \mathrm{O}\right)\right] \cdot$ $\mathrm{H}_{2} \mathrm{O}$, en = ethylenediamine), ${ }^{, \mathrm{b}}$ and $\mathrm{NaM}\left\{\mathrm{O}_{3} \mathrm{PCH}(\mathrm{OH}) \mathrm{CO}_{2}\right\}$ $(\mathrm{M}=\mathrm{Mn}, \mathrm{Fe}, \mathrm{Co}, \mathrm{Zn}){ }^{9 \mathrm{~d}, 10}$ It must be noted that anionic metalphosphonate complexes can be formed in solution prior to precipitation and, hence, at high $\mathrm{pH}$ values, additional monovalent cations may be needed to neutralize the charge. Until now, no comprehensive studies to determine the influence of the added base have been reported. In Table 1, all M(II)-hydroxyphosphonoacetate compounds with 1:1 molar ratios reported so far are collectively presented, with structures of $1 \mathrm{D}, 2 \mathrm{D}$, and $3 \mathrm{D}$ dimensionality. It is noteworthy to emphasize the large diversity in structural architectures for M(II)-HPAA hybrids with 1:1 metal/ligand molar ratio.

(10) (a) Lai, Z.; Fu, R.; Hu, S.; Wu, X. Eur. J. Inorg. Chem. 2007, 54395446. (b) Cui, L.; Sun, Z.; Chen, H.; Meng, L.; Dong, D.; Tian, C.; Zhu, Z.; You, W. J. Coord. Chem. 2007, 60, 1247-1254. (c) Li, J.; Zhu, Y.-Y.; Huang, C.-Y.; Sun, Z.-G.; Dong, D.-P. Acta Crystallogr. 2007, E63, m2350. (d) Sun, Z.; Cui, L.; Liu, Z.; Meng, L.; Chen, H.; Dong, D.; Zhang, L.; Zhu, Z.; You, W. Inorg. Chem. Commun. 2006, 9, 999-1001.

(11) (a) Li, J.; Meng, L.; Sun, Z.-G.; Cui, L.-Y.; Zhang, J.; Zhang, Y.-Y.; Dong, D.-P.; Chen, H.; You, W.-S.; Zhu, Z.-M. Inorg. Chem. Commun. 2007, 10, 535-537. (b) Zhu, Y.-Y.; Li, J.; Sun, Z.-G.; Zhang, J.; Zhao, Y.; Lu, X.; Liu, L.; Zhang, N. Z. Anorg. Allg. Chem. 2009, 635, 171-174.
In this article, we report the synthesis and characterization of new hybrids prepared both at RT and by hydrothermal reactions. Hence, a series of magnesium, cobalt, nickel, copper, and zinc hydroxyphosphonoacetate 1D compounds is thoroughly studied. The effects of the reaction temperature, $\mathrm{pH}$, and the presence/absence of alkali metal hydroxides on the resulting $\mathrm{M}$ (II) hydroxyphosphonoacetate frameworks have also been investigated.

\section{Experimental Section}

General Procedures. All water-soluble metal salts were commercial samples and were used without further purification. A racemic mixture of $R, S$-HPAA $(50 \% \mathrm{w} / \mathrm{w}$ stock solution in water) was from Biolab, U.K. Stock solutions of $\mathrm{HCl}$ and $\mathrm{MOH}$ $\left(\mathrm{M}=\mathrm{Na}^{+}, \mathrm{K}^{+}\right)$were used for $\mathrm{pH}$ adjustments. In-house, deionized (DI) water was used for all syntheses. A parallel synthesis procedure was applied to obtain solids by hydrothermal reactions. The autoclave block is made of aluminum and contains 6 reaction chambers in a $3 \times 2$ array. Teflon reactors have an inner diameter of $19 \mathrm{~mm}$ and a depth of $18 \mathrm{~mm}$, with a total volume of about $5 \mathrm{~mL}$. A thin sheet of Teflon covers the reaction vessels, which are then sealed inside a specially designed aluminum autoclave. Elemental analyses $(\mathrm{C}, \mathrm{H}, \mathrm{N})$ were measured on a Perkin-Elmer 240 analyzer. Thermogravimetric analysis (TGA) data were recorded on an SDT-Q600 analyzer from TA Instruments. The temperature varied from RT to $500{ }^{\circ} \mathrm{C}$ at a heating rate of $4{ }^{\circ} \mathrm{C} \cdot \mathrm{min}^{-1}$. Measurements were carried out on samples in open platinum crucibles under a flow of air. It must be noted that the reported yields, given below, are based on the metals.

The following labeling scheme is followed throughout the manuscript for all compounds reported herein, see Table 1 and Scheme 1. The general notation is $\mathbf{M}(\mathbf{A})-\mathbf{L}-\mathbf{x}-\mathbf{y}-\mathbf{n D}$. The symbols stand for: $\mathbf{M}$ a divalent cation; $\mathbf{A}$ the charge-compensating cation (present only in some cases); $\mathbf{L}$ the anionic HPAA ${ }^{2-/ 3-}$ ligand; $\mathbf{x}$ the number of metal-bound water molecules; $\mathbf{y}$ the number of lattice water molecules; and $\mathbf{n}$ the dimensionality of the framework.

Materials Syntheses. Mg-L-2-2-1D, Mg-L-2-0-1D, and MgL-0-0-3D. $\mathrm{MgCl}_{2} \cdot 6 \mathrm{H}_{2} \mathrm{O}(4.39 \mathrm{mmol})$ was added to a solution formed by $1.0 \mathrm{~mL}$ of the ligand stock solution $(4.39 \mathrm{mmol})$ and DI water $(25 \mathrm{~mL})$ under vigorous stirring. Solution $\mathrm{pH}$ was adjusted to the desired value $(2,2.7,2.9,3.2$, and 3.3) with 5.0 or 1.0 $\mathrm{M} \mathrm{NaOH}$ stock solutions. Mg-L-2-2-1D was obtained at $\mathrm{pH}=2$ while Mg-2-0-1D crystallized above $\mathrm{pH}$ 2.7. The clear, slightly yellow solutions were stored at RT. All reaction solutions precipitated microcrystalline materials after 3 days (yield 
Scheme 1. Pseudo Phase Diagram Showing the Temperature and $\mathrm{pH}$ Values of the Syntheses for the Metal-HPAA Hybrids (Bottom) ${ }^{a}$

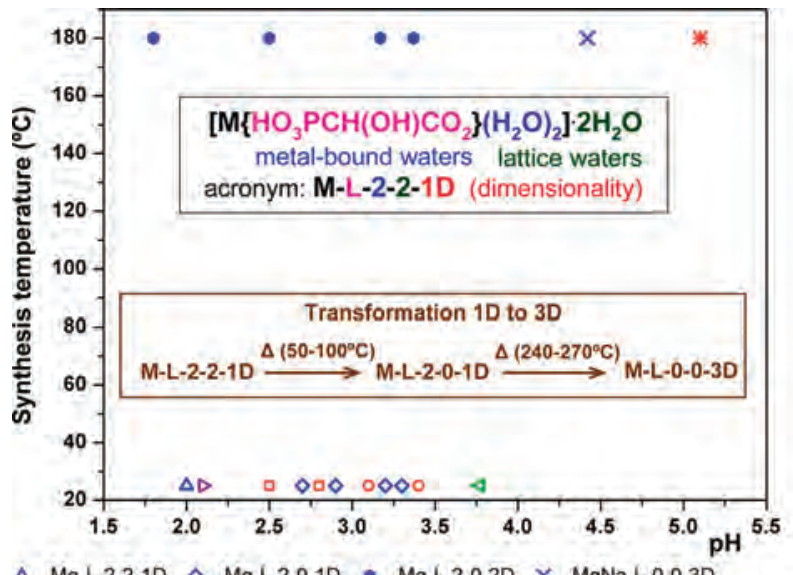

$\triangle M g-L-2-2-1 D \diamond M g-L-2-0-1 D * M g-L-2-0-2 D \times M g N a-L-0-0-3 D$

a Zn-L-2-2-1D $\circ$ Zn-L-2-0-1D $\%$ Znk-L-0-0-3D 4 Co-L-2-2-1D D Ni-L-2-2-1C

${ }^{a}$ The upper inset shows the acronym system used to name the hybrids. The lower inset shows the average dehydration temperatures for the $1 \mathrm{D}$ solids.

$45 \%$ ). If crystallization is maintained over 1 week, higher yields are obtained $(70 \%)$. The precipitates were isolated by filtration (without washing) and air-dried. Anal. Calcd (\%) for $\mathrm{Mg}-$ $\mathrm{PC}_{2} \mathrm{O}_{10} \mathrm{H}_{11}$ (Mg-L-2-2-1D): C, 9.59; H, 4.23. Found: C, 9.33; $\mathrm{H}, 3.48$. Anal. Calcd (\%) for $\mathrm{MgPC}_{2} \mathrm{O}_{8} \mathrm{H}_{7}$ (Mg-L-2-0-1D): C, 11.21; H, 3.29. Found: C, 10.44; H, 3.00. Mg-L-0-0-3D was prepared by heating $\mathbf{M g}-\mathbf{L}-2-2-1 \mathrm{D}$ at $270{ }^{\circ} \mathrm{C}$ for $3 \mathrm{~h}$.

Zn-L-2-2-1D, Zn-L-2-0-1D, and Zn-L-0-0-3D. A synthetic procedure similar to that reported above for the analogous magnesium derivatives was used. For example, $0.2 \mathrm{~mL}$ of the HPAA stock solution $(0.88 \mathrm{mmol})$ was reacted with $\mathrm{ZnCl}_{2}(0.88$ mmol, 1:1 molar ratio) in $25 \mathrm{~mL}$ of DI water. Solution $\mathrm{pH}$ was adjusted to the desired value $(2.5,2.8,3.1$, and 3.3$)$ with 5.0 or 1.0 $\mathrm{M} \mathrm{NaOH}$ stock solutions. All reaction solutions precipitated crystalline material after 3 days at RT (yield 50\%). Zn-L-2-2-1D was obtained as a single phase solid, at $\mathrm{pH}$ 2.5-2.8. Higher

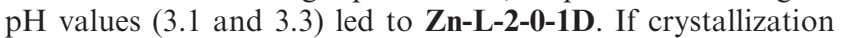
is allowed to proceed over 3 days, higher yields are obtained $(\sim 60 \%)$. The precipitates were isolated by filtration and airdried. Anal. Calcd (\%) for $\mathrm{ZnPC}_{2} \mathrm{O}_{10} \mathrm{H}_{11}$ (Zn-L-2-2-1D): C, 8.24; H, 3.80. Found: C, 7.85; H, 2.35. Anal. Calcd (\%) for $\mathrm{ZnPC}_{2} \mathrm{O}_{8} \mathrm{H}_{7}$ (Zn-L-2-0-1D): C, 9.40; H, 2.76. Found: C, 9.49; H, 2.77. Zn-L-0-0-3D was prepared by heating Zn-L-2-2-1D at $240{ }^{\circ} \mathrm{C}$ for $3 \mathrm{~h}$.

Mg-L-2-0-2D. $\mathrm{Mg}\left(\mathrm{NO}_{3}\right)_{2} \cdot 6 \mathrm{H}_{2} \mathrm{O}$ or $\mathrm{MgO}$ were separately reacted with a solution of the ligand and a fixed molar ratio $\mathrm{Mg}: \mathrm{L}=1: 1$. A crystalline single phase compound was obtained in the $\mathrm{pH}$ range $2-3.2$ adjusted by adding $1 \mathrm{M} \mathrm{NaOH}$ or $1 \mathrm{M}$ $\mathrm{HNO}_{3}$. The reactions were maintained for 3 days at $180^{\circ} \mathrm{C}$. The resulting solids were filtered off, washed twice with DI water, and dried at $50{ }^{\circ} \mathrm{C}$ (yield 84\%). Anal. Calcd $(\%)$ for $\mathrm{MgPC}_{2} \mathrm{O}_{8} \mathrm{H}_{7}$ (Mg-L-2-0-2D): C, 11.21; H, 3.29. Found: C, $10.53 ; \mathrm{H}, 3.02$.

Co-L-2-2-1D. A volume of the HPAA stock solution $(2 \mathrm{~mL}$, $8.78 \mathrm{mmol})$ was reacted with $\mathrm{CoCl}_{2}(8.78 \mathrm{mmol}, 1: 1$ molar ratio) in DI water $(250 \mathrm{~mL})$. Solution $\mathrm{pH}$ was adjusted to 3.77 with 5.0 or $1.0 \mathrm{M} \mathrm{NaOH}$ stock solutions. The reaction solution precipitated microcrystalline material after 7 days at RT. Yield $\sim 70 \%$.

Ni-L-2-1-1D. A volume of the HPAA stock solution $(2 \mathrm{~mL}$, $8.78 \mathrm{mmol})$ was reacted with $\mathrm{NiCl}_{2}(8.78 \mathrm{mmol}, 1: 1$ molar ratio) in DI water $(200 \mathrm{~mL})$. Solution $\mathrm{pH}$ was adjusted to 2.0 with 5.0 or $1.0 \mathrm{M} \mathrm{NaOH}$ stock solutions. The reaction solution precipitated microcrystalline material after 7 days at RT. Yield $\sim 50 \%$.

MgNa-L-0-0-3D and ZnK-L-0-0-3D. A variant of the synthesis procedure already described ${ }^{7}$ was followed. Hydrothermal reactions were conducted at $180^{\circ} \mathrm{C}$ for 3 days. $\mathrm{M} / \mathrm{L}$ molar ratios $1: 1,1: 4$ and $1: 8$ were assayed. The salts $\mathrm{Zn}\left(\mathrm{CH}_{3} \mathrm{COO}\right)_{2} \cdot 2 \mathrm{H}_{2} \mathrm{O}$ and $\mathrm{Mg}\left(\mathrm{CH}_{3} \mathrm{COO}\right)_{2} \cdot 4 \mathrm{H}_{2} \mathrm{O}$ were separately added to a solution formed by mixing together $0.5 \mathrm{~mL}$ of the HPAA stock solution (2.23 mmol), $0.5 \mathrm{~mL}$ of DI water, $0.78 \mathrm{~mL}$ of glacial acetic acid (14 mmol), and $14 \mathrm{mmol}$ of sodium or potassium acetate. Final $\mathrm{pH}$ values were $5.1\left(\mathrm{Zn}^{2+}\right.$ derivatives $)$ and $4.4\left(\mathrm{Mg}^{2+}\right.$ derivatives). For both series of materials, crystalline single phase solids were obtained using M/L 1:4 and 1:8 molar ratios. The resulting solids were filtered off, washed twice with DI water and then with acetone, and finally dried at $50{ }^{\circ} \mathrm{C}$. The resulting yields for MgNa-L-0-0-3D and ZnK-L-0-0-3D were 95 and $68 \%$, respectively. Anal. Calcd (\%) for $\mathrm{MgNaPC}_{2} \mathrm{O}_{6} \mathrm{H}_{2}(\mathbf{M g N a}-\mathrm{L}-$ 0-0-3D): C, 11.99; H, 1.01. Found: C, 10.88; H, 1.19. Anal. Calcd (\%) for $\mathrm{ZnKPC}_{2} \mathrm{O}_{6} \mathrm{H}_{2}$ (ZnK-L-0-0-3D): C, 9.32; H, 0,78. Found: C, 8.87; H, 1.01.

X-ray Crystallography. Laboratory X-ray powder diffraction (XRPD) patterns were collected on a PANanalytical X'Pert Pro automated diffractometer. Powder patterns were recorded in Bragg-Brentano reflection configuration by using a $\mathrm{Ge}(111)$ primary monochromator $\left(\mathrm{Cu} \mathrm{K} \alpha_{1}\right)$ and the X'Celerator detector with a step size of $0.017^{\circ}(2 \theta)$. The powder patterns were recorded between 5 and $100^{\circ}$ in $2 \theta$ with an equivalent counting time of $\sim 712 \mathrm{~s} / \mathrm{step}$. The powder patterns of $\mathbf{M g - L - 2 - 2 - 1 D}$ and Zn-L-2-0-1D for ab initio structural determination (samples were loaded within sealed $0.5 \mathrm{~mm}$ borosilicate glass capillaries) were recorded in Debye-Scherrer transmission configuration by using a hybrid $\mathrm{Ge}(220)$ primary monochromator $\left(\mathrm{Cu} \mathrm{K} \alpha_{1}\right.$ radiation) and the $X^{\prime}$ Celerator detector. The XRPD patterns were recorded between 4 and $90^{\circ}(2 \theta), 0.017^{\circ}$ step size and an equivalent counting time of about $1000 \mathrm{~s} / \mathrm{step}$. Because of the lability of the lattice water molecules for cobalt and nickel compounds, XRPD data were collected using an accumulative scan mode between 4 and $60^{\circ}(2 \theta)$ and an equivalent counting time of $40 \mathrm{~s} / \mathrm{step}$.

Thermodiffractometric studies for M-L-2-2-1D $(\mathrm{M}=\mathrm{Mg}$, $\mathrm{Zn}$ ) and Mg-L-2-0-2D were carried out using an Anton Paar TTK450 Camera under static air. Flux of gases was not employed to avoid sample dehydration prior to the diffraction experiment. Data were collected at different temperature intervals ranging between 20 and $40^{\circ} \mathrm{C}$, from RT to 240 (Zn-L-2-21D) or $270{ }^{\circ} \mathrm{C}$ (Mg-L-2-2-1D) with a delay time of $15 \mathrm{~min}$ to ensure thermal stabilization. The data acquisition range was $4-50^{\circ}(2 \theta)$ with a step size of $0.017^{\circ}$. X-ray powder diffraction data for the Rietveld refinements of M-L-0-0-3D (M $=\mathrm{Zn}, \mathbf{M g})$ were recorded in reflection mode by heating the samples in situ at 240 and $270{ }^{\circ} \mathrm{C}$, respectively. After $15 \mathrm{~min}$ at the selected temperature, diffraction data were collected between 4 and $70^{\circ}(2 \theta)$, step size $0.017^{\circ}$, and an equivalent counting times of $300 \mathrm{~s} / \mathrm{step}$.

Structure Determination. X-ray powder patterns corresponding to the single phases were autoindexed using the DICVOL06 program. ${ }^{12}$ The crystal structure of Mg-L-2-2-1D and Zn-L-2-01D were solved following an ab initio methodology. Structure determination by direct methods was carried out using the program EXPO2009 and EXPO2004 ${ }^{13}$, respectively. The content of the asymmetric units were given by default setting except for the oxygen of the water molecules. The missing atoms were localized by difference of Fourier maps. The crystal structures of M-L-2-2-1D ( $\mathrm{M}=\mathrm{Zn}, \mathrm{Co})$ compounds were determined by the Rietveld method ${ }^{14}$ using the structure of Mg-L-2-2-1D as starting model. The crystal structures of M-L-2-0-1D $(\mathrm{M}=\mathrm{Mg}, \mathrm{Ni}$, Co) compounds were determined by the Rietveld method ${ }^{14}$

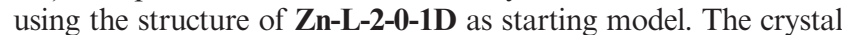
structures of M-L-0-0-3D (M = Mg, Zn), MgNa-L-0-0-3D and

(12) Boultif, A.; Louer, D. J. Appl. Crystallogr. 2004, 37, 724-731.

(13) Altomare, A.; Caliandro, R.; Camalli, M.; Cuocci, C.; Giacovazzo, C.; Moliterni, A.; Rizzi, R. J. Appl. Crystallogr. 2004, 37, 1025-1028.

(14) Rietveld, H. M. J. Appl. Crystallogr. 1969, 2, 65-71. 
Table 2. Crystallographic Data for 1D Metal Hydroxyphosphonoacetate Hybrid Materials

\begin{tabular}{|c|c|c|c|c|c|c|}
\hline phase & Mg-L-2-2-1D & Mg-L-2-0-1D & Co-L-2-2-1D ${ }^{b}$ & Co-L-2-0-1D ${ }^{b}$ & Zn-L-2-2-1D & Zn-L-2-0-1D \\
\hline empirical formula & $\mathrm{MgC}_{2} \mathrm{H}_{11} \mathrm{O}_{10} \mathrm{P}$ & $\mathrm{MgC}_{2} \mathrm{H}_{7} \mathrm{O}_{8} \mathrm{P}$ & $\mathrm{CoC}_{2} \mathrm{H}_{11} \mathrm{O}_{10} \mathrm{P}$ & $\mathrm{CoC}_{2} \mathrm{H}_{7} \mathrm{O}_{8} \mathrm{P}$ & $\mathrm{ZnC}_{2} \mathrm{H}_{11} \mathrm{O}_{10} \mathrm{P}$ & $\mathrm{ZnC}_{2} \mathrm{H}_{7} \mathrm{O}_{8} \mathrm{P}$ \\
\hline F.W. $\left(\mathrm{g} \cdot \mathrm{mol}^{-1}\right)$ & 250.38 & 214.35 & 285.01 & 248.97 & 291.47 & 255.43 \\
\hline space group & Pbca & $P 2_{1} / b 11$ & Pbca & Pbca & Pbca & Pbca \\
\hline$a\left(\AA_{0}\right)$ & $8.58799(10)$ & $8.80982(19)$ & $8.596(1)$ & $8.755(1)$ & $8.55368(10)$ & $8.74511(16)$ \\
\hline$b(\AA)$ & $9.78703(12)$ & $9.85013(19)$ & $9.767(1)$ & $9.816(1)$ & $9.79697(13)$ & $9.83590(18)$ \\
\hline$c(\AA)$ & $21.83420(26)$ & $16.79792(31)$ & $21.845(3)$ & $16.891(1)$ & $21.89928(34)$ & $16.8469(4)$ \\
\hline$\alpha(\operatorname{deg})$ & 90.0 & $93.3399(25)$ & 90.0 & 90.0 & 90.0 & 90.0 \\
\hline$\beta(\operatorname{deg})$ & 90.0 & 90.0 & 90.0 & 90.0 & 90.0 & 90.0 \\
\hline$\gamma(\mathrm{deg})$ & 90.0 & 90.0 & 90.0 & 90.0 & 90.0 & 90.0 \\
\hline$V\left(\AA^{3}\right)$ & $1835.19(5)$ & $1455.21(6)$ & $1834.0(5)$ & $1451.6(4)$ & $1835.16(5)$ & $1449.10(6)$ \\
\hline$Z$ & 8 & 8 & 8 & 8 & 8 & 8 \\
\hline$V\left(\AA^{3} \text { atom }^{-1}\right)^{a}$ & 16.38 & 15.16 & 16.38 & 15.12 & 16.39 & 15.09 \\
\hline$\rho_{\text {calc }}\left(\mathrm{g} \cdot \mathrm{cm}^{-3}\right)$ & 1.732 & 1.892 & 1.984 & 2.214 & 2.030 & 2.277 \\
\hline $2 \theta$ range (deg) & $10.00-89.99$ & $8.00-99.97$ & & & $4.01-99.99$ & $5.02-99.98$ \\
\hline data/restraints/ parameters & $4706 / 22 / 81$ & $5411 / 41 / 114$ & & & $5352 / 21 / 80$ & $5175 / 20 / 57$ \\
\hline no. reflections & 742 & 1506 & & & 1692 & 742 \\
\hline$R_{\mathrm{wp}}$ & 0.0463 & 0.0582 & & & 0.0563 & 0.0848 \\
\hline$R_{\mathrm{p}}$ & 0.0358 & 0.0442 & & & 0.0440 & 0.0614 \\
\hline$R_{\mathrm{F}}$ & 0.0424 & 0.0352 & & & 0.0257 & 0.0421 \\
\hline CCDC reference code & 750171 & 750170 & & & 750175 & 750174 \\
\hline
\end{tabular}

${ }^{a}$ Volume per non-hydrogen atom. ${ }^{b}$ Structural parameters are not reported because of the low quality of their X-ray powder diffraction patterns.

Table 3. Crystallographic Data for 2D and 3D Metal Hydroxyphosphonoacetate Hybrid Materials

\begin{tabular}{|c|c|c|c|c|c|}
\hline phase & Mg-L-2-0-2D & Mg-L-0-0-3D & MgNa-L-0-0-3D & Zn-L-0-0-3D ${ }^{b}$ & ZnK-L-0-0-3D \\
\hline empirical formula & $\mathrm{MgC}_{2} \mathrm{H}_{7} \mathrm{O}_{8} \mathrm{P}$ & $\mathrm{MgC}_{2} \mathrm{H}_{3} \mathrm{O}_{6} \mathrm{P}$ & $\mathrm{MgNaC}_{2} \mathrm{H}_{2} \mathrm{O}_{6} \mathrm{P}$ & $\mathrm{ZnC}_{2} \mathrm{H}_{3} \mathrm{O}_{6} \mathrm{P}$ & $\mathrm{ZnKC}_{2} \mathrm{H}_{2} \mathrm{O}_{6} \mathrm{P}$ \\
\hline F.W. $\left(\mathrm{g} \cdot \mathrm{mol}^{-1}\right)$ & 214.35 & 178.32 & 200.30 & 219.41 & 257.49 \\
\hline space group & $P 2_{1} / c$ & Pbca & Pbca & Pbca & $P n a 2_{1}$ \\
\hline$a(\AA)$ & $5.69261(7)$ & $8.6374(7)$ & $10.19057(10)$ & $8.709(2)$ & $10.28057(14)$ \\
\hline$b(\AA)$ & $15.61430(18)$ & $9.6892(9)$ & $9.69876(10)$ & $9.792(2)$ & $12.28914(17)$ \\
\hline$c(\AA)$ & $7.82600(10)$ & $11.8164(20)$ & $10.82375(9)$ & $11.807(3)$ & $5.03253(6)$ \\
\hline$\alpha(\operatorname{deg})$ & 90.0 & 90.0 & 90.0 & 90.0 & 90.0 \\
\hline$\beta$ (deg) & $110.1581(8)$ & 90.0 & 90.0 & 90.0 & 90.0 \\
\hline$\gamma(\operatorname{deg})$ & 90.0 & 90.0 & 90.0 & 90.0 & 90.0 \\
\hline$V\left(\AA^{3}\right)$ & $653.01(2)$ & $988.9(2)$ & $1069.77(2)$ & $1007.0(5)$ & $635.807(18)$ \\
\hline$Z$ & 4 & 8 & 8 & 8 & 4 \\
\hline$V\left(\AA^{3} \text { atom }^{-1}\right)^{a}$ & 13.60 & 12.36 & 12.16 & 12.58 & 14.45 \\
\hline$\rho_{\text {calc }}\left(\mathrm{g} \cdot \mathrm{cm}^{-3}\right)$ & 2.108 & 2.355 & 2.462 & 2.854 & 2.669 \\
\hline $2 \theta$ range $(\mathrm{deg})$ & $3.96-99.94$ & $5.03-69.99$ & $3.82-99.81$ & & $3.92-99.90$ \\
\hline data/restraints/parameters & $5646 / 20 / 76$ & $3322 / 18 / 53$ & $5059 / 23 / 56$ & & $5353 / 23 / 54$ \\
\hline no. reflections & 667 & 217 & 431 & & 332 \\
\hline$R_{\mathrm{wp}}$ & 0.0995 & 0.0650 & 0.0681 & & 0.0823 \\
\hline$R_{\mathrm{p}}$ & 0.0704 & 0.0510 & 0.0491 & & 0.0624 \\
\hline$R_{\mathrm{F}}$ & 0.0397 & 0.0460 & 0.0416 & & 0.0324 \\
\hline CCDC reference code & 750172 & 750169 & 750173 & & 750176 \\
\hline
\end{tabular}

${ }^{a}$ Volume per non-hydrogen atom. ${ }^{b}$ Structural parameters are not reported because of the low quality of their X-ray powder diffraction patterns.

ZnK-L-0-0-3D were refined using as starting models those of $\mathbf{C u}-\mathbf{L}-$ 0-0-3D, ${ }^{8 \mathrm{c}}$ MNa-L-0-0-3D ${ }^{10 a}(\mathrm{M}=\mathrm{Fe}, \mathrm{Mn}, \mathrm{Co}, \mathrm{Zn})$, and $\mathbf{Z n N H}_{\mathbf{4}^{-}}$ L-0-0-3D, ${ }^{7}$ respectively. All crystal structures were refined by the Rietveld method $^{14}$ by using the GSAS package ${ }^{15}$ with soft constraints to maintain chemically reasonable geometries for the phosphonate, chain, and carboxylic groups. The soft constraints were as follows: $/ \mathrm{PO}_{3} \mathrm{C}_{1}$ tetrahedron/ $\mathrm{P}-\mathrm{O}[1.53(1) \AA], \mathrm{P}-\mathrm{C}_{1}$

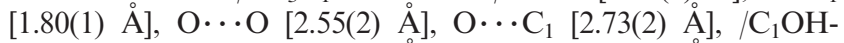
$\mathrm{C}_{2} \mathrm{OO}$ group $/ \mathrm{C}_{1}-\mathrm{C}_{2}$ [1.50(1) $\left.\mathrm{A}\right], \mathrm{C}_{2}-\mathrm{O}_{\text {carb }}$ [1.23(1) $\AA$ ], $\mathrm{C}_{1}-\mathrm{OH}$ $\left[\begin{array}{ll}1.40(1) \AA & \AA\end{array}\right], \quad \mathrm{P} \cdot \mathrm{OH} \quad[2.68(2) \AA], \quad \mathrm{C}_{2}-\mathrm{OH} \quad[2.40(2) \AA]$, $\mathrm{O}_{\text {carb }} \cdots \mathrm{O}_{\text {carb }}[2.21(2) \AA]$ and $\mathrm{C}_{1} \cdots \mathrm{O}_{\text {carb }}[2.36(2) \AA]$. Hydrogen atoms were not included in the refinements. Crystallographic data are presented in Tables 2 and 3 and the final Rietveld plots are given in the Supporting Information. Crystal structures have been deposited at the CCDC, and the reference codes given at the bottom of Tables 2 and 3.

(15) (a) Toby, B. H. J. Appl. Crystallogr. 2001, 34, 210-213. (b) Larson, A. C.; von Dreele, R. B. Los Alamos National Laboratory, Report No. LA-UR$86-748,2000$.

\section{Results and Discussion}

Metal(II) hydroxyphosphonoacetate hybrid materials exhibit a rich variety of structural architectures. This is shown in Table 1, where all reported phases are gathered, and exemplified by the $\mathrm{M}\left\{\mathrm{HO}_{3} \mathrm{PCH}(\mathrm{OH}) \mathrm{CO}_{2}\right\}\left(\mathrm{H}_{2} \mathrm{O}\right)_{2}$, M-L-20, stoichiometry. For $\mathrm{M}=\mathrm{Ni}, \mathrm{Cu},{ }^{8 \mathrm{c}} \mathrm{Mg}, \mathrm{Co}, \mathrm{Zn}, 1 \mathrm{D}$ compounds are isolated by room-temperature crystallization or by heating compounds of higher hydration degrees. For $\mathrm{M}=\mathrm{Mn}, \mathrm{Fe}, \mathrm{Co}, \mathrm{Zn},{ }^{9 \mathrm{a}}$ and $\mathrm{Mg}$, layered materials are hydrothermally obtained. Furthermore, for $\mathrm{M}=\mathrm{Sr}, \mathrm{Ba}^{4}$ compounds with $3 \mathrm{D}$ structures have also been isolated. The most relevant synthetic conditions (temperature and $\mathrm{pH}$ ) used for the preparations of the hybrids reported in this study are summarized in Scheme 1, which gathers both RT and hydrothermal syntheses.

M-L-2-2-1D ( $\mathrm{M}=\mathrm{Mg}, \mathrm{Co}$, and $\mathrm{Zn}$ ) compounds crystallize with four water molecules per chemical formula, and they have not been previously reported. Although compounds M-L-2-2-1D and M-L-2-0-1D ( $\mathrm{M}=\mathbf{M g}$ and $\mathrm{Zn})$ 
may be assumed to have similar stabilities, their dehydration behavior reveals very surprising results. $\left[\mathrm{M}\left\{\mathrm{HO}_{3} \mathrm{PCH}(\mathrm{OH})-\right.\right.$ $\left.\left.\mathrm{CO}_{2}\right\}\left(\mathrm{H}_{2} \mathrm{O}\right)_{2}\right] \cdot 2 \mathrm{H}_{2} \mathrm{O},(\mathrm{M}=\mathrm{Mg}, \mathrm{Zn})$ are dehydrated to $\mathrm{M}$ $\left\{\mathrm{HO}_{3} \mathrm{PCH}(\mathrm{OH}) \mathrm{CO}_{2}\right\}\left(\mathrm{H}_{2} \mathrm{O}\right)_{2}$ when they are placed in contact with liquid water! Furthermore, if M-L-2-2-1D compounds are suspended in liquid water with a $\mathrm{pH}$ previously adjusted to 2.5 with $\mathrm{HCl}, \mathbf{M}-\mathbf{L}-2-\mathbf{0}-\mathbf{1 D}$ compounds are still formed. These counterintuitive results are justified because M-L-2-2$1 \mathrm{D}$ are only stable in contact with liquid water if its $\mathrm{pH}$ is lower than approximately 3.0 (it slightly depends upon the nature of the divalent metal) and the solution contains HPAA ligand. Furthermore, if a suspension of Mg-L-2-2$1 \mathrm{D}$ crystals, in the liquid mother, is heated at $60^{\circ} \mathrm{C}$ for 1 day,

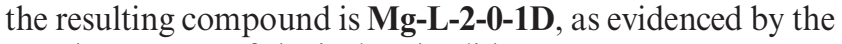
powder pattern of the isolated solid.

Single phase compounds with 1D structures, M-L-2-2-1D $(\mathrm{M}=\mathrm{Mg}, \mathrm{Co}, \mathrm{Zn})$, can be isolated at $\mathrm{RT}$ at $\mathrm{pH}$ values lower than 2.7, 3.77, and 3.0, respectively. Syntheses at $\mathrm{pH}$ values slightly higher than those previously given yielded M-L-2-01D-type compounds. M-L-2-0-1D phases were also prepared by washing the corresponding M-L-2-2-1D compounds with DI water. As synthesized, the nickel derivative was a poorly

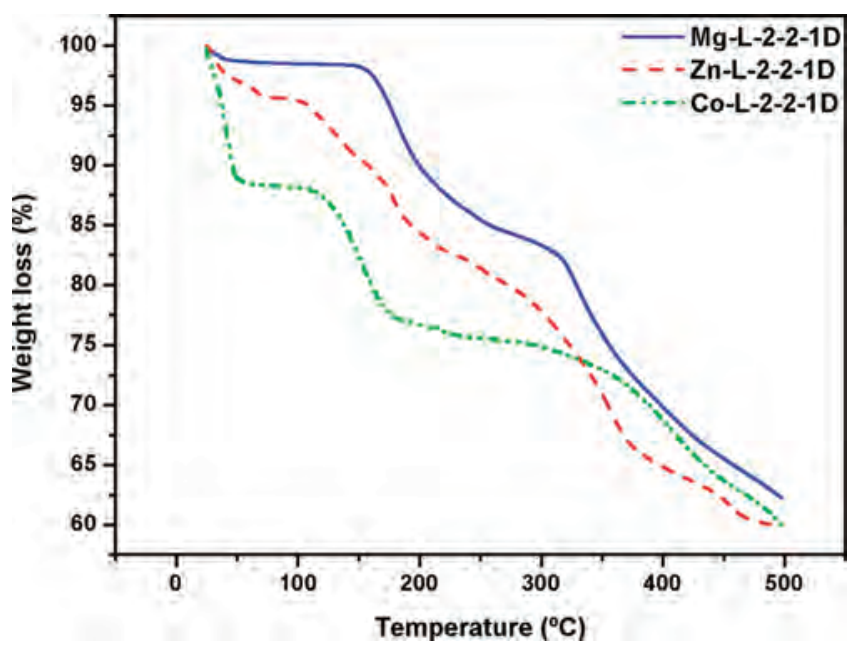

Figure 1. TGA curves for $\left[\mathrm{M}\left\{\mathrm{HO}_{3} \mathrm{PCH}(\mathrm{OH}) \mathrm{CO}_{2}\right\}\left(\mathrm{H}_{2} \mathrm{O}\right)_{2}\right] \cdot 2 \mathrm{H}_{2} \mathrm{O}$, $\mathrm{M}=\mathrm{Mg}, \mathrm{Co}, \mathrm{Zn}$. crystalline solid. Its XRPD pattern shows only a few diffraction peaks, and it fits closely that of the copper derivative containing only one lattice water molecule, Cu-L-2-1-1D. ${ }^{8 b}$ The crystallinity of the nickel derivative was significantly improved by drying the sample at $60{ }^{\circ} \mathrm{C}$. A Rietveld analysis of the pattern of this sample (see the Supporting Information), using the structures of $\mathbf{C u}-\mathbf{L}-\mathbf{2}-\mathbf{- 1}-\mathbf{1 D}^{8 \mathrm{~b}}$ and $\mathbf{~ N i}$ L-2-0-1D ${ }^{8 a}$ as starting models gave a mixture of 36.5(4) wt \% of Ni-L-2-1-1D and 63.5(1) wt \% Ni-L-2-0-1D. On the other hand, the lattice water is very loosely held in Co-L-2-2-1D which rendered the determination of its precise crystal structure impossible. However, a Rietveld refinement from fast diffraction data, and refining only non-atomic parameters, confirmed that this phase is isostructural to that of $\mathrm{Mg}$ and $\mathrm{Zn}$ derivatives. The refined unit cell parameters of Co-L-2-2-1D were $a=8.596(1) \AA, b=8.597(1) \AA, c=$ $21.845(2) \AA$, and $V=1834.0(5) \AA^{3}$, in close agreement with those obtained for $\mathrm{Mg}$ and $\mathrm{Zn}$ compounds, see Table 2. The final Rietveld fit is shown in the Supporting Information. Powder pattern with large counting times for Co-L-2-2-1D invariably lead to partial dehydration of the compound during the measurement.

TGA data for compounds M-L-2-2-1D $(\mathrm{M}=\mathrm{Mg}, \mathrm{Co}$, and $\mathrm{Zn}$ ) are depicted in Figure 1. The TG curves show that the lattice water is lost at very low temperatures, below 50$60{ }^{\circ} \mathrm{C}$. Furthermore, for $\mathrm{M}=\mathrm{Mg}$, the compound is readily dehydrated under air-flow which is necessary to carry out the measurement in the equipment described in the Experimental Section. The plateaus observed below $\sim 100^{\circ} \mathrm{C}$ correspond to the existence of $\mathbf{M - L - 2 - 0 - 1 D}(\mathbf{M}=\mathbf{M g}, \mathrm{Co}$, and $\mathrm{Zn})$ compounds. The thermal stability of M-L-2-0-1D $(\mathrm{M}=$ $\mathrm{Mg}, \mathrm{Co}$, and $\mathrm{Zn}$ ) varies notably, being 90,105 , and $150{ }^{\circ} \mathrm{C}$ for $\mathrm{M}=\mathrm{Zn}, \mathrm{Co}$, and $\mathrm{Mg}$, respectively. Fully dehydrated compounds, M-L-0-0-3D ( $\mathrm{M}=\mathrm{Mg}, \mathrm{Co}$, and $\mathrm{Zn})$, are formed at temperature slightly above of $200{ }^{\circ} \mathrm{C}$.

Thermodiffraction studies were carried out to closely follow the thermal evolution of the $1 \mathrm{D}$ compounds. Figure 2 shows the thermodiffraction pattern of sample Mg-L-2-2-1D which is representative of the series with four water molecules per chemical formula. In the first step of dehydration, $\mathbf{M g}-\mathbf{L}-$

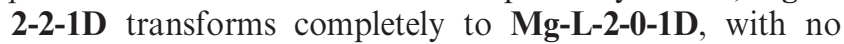
lattice water present, below $90^{\circ} \mathrm{C}$. This result is in agreement

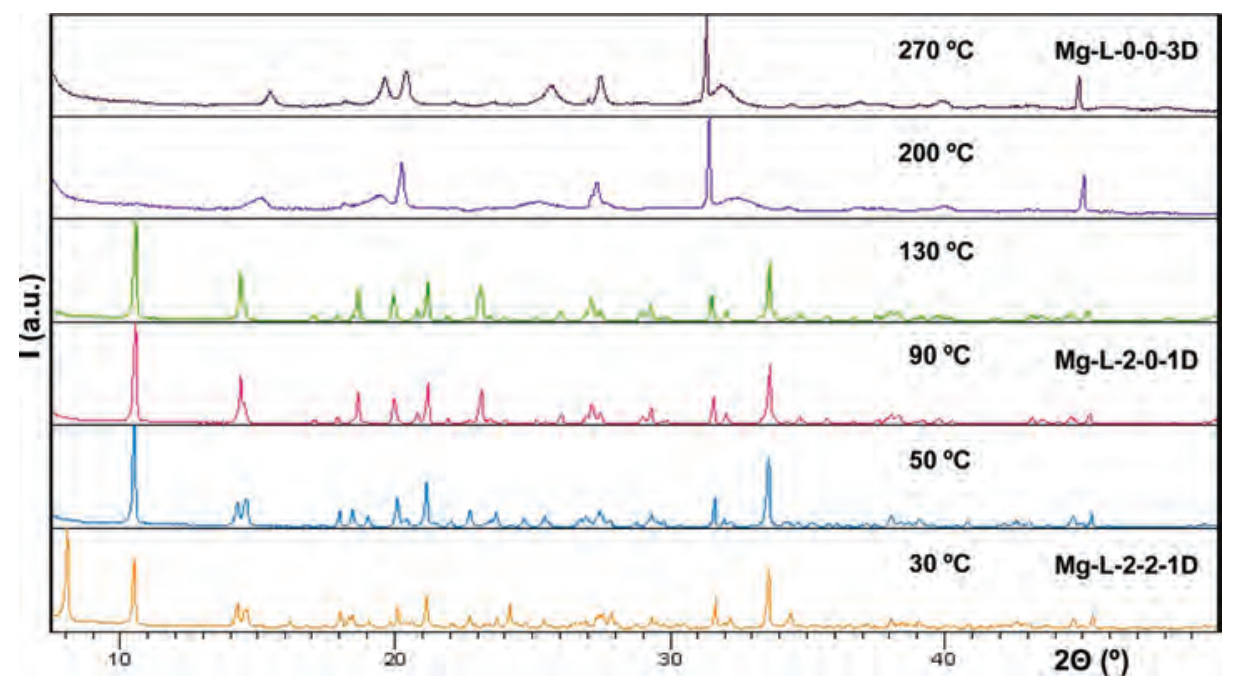

Figure 2. Thermodiffractometric study for $\left[\mathrm{Mg}\left\{\mathrm{HO}_{3} \mathrm{PCH}(\mathrm{OH}) \mathrm{CO}_{2}\right\}\left(\mathrm{H}_{2} \mathrm{O}\right)_{2}\right] \cdot 2 \mathrm{H}_{2} \mathrm{O}$. Two sharp peaks at 31.5 and $45.5^{\circ}(2 \Theta)$ are due to a small impurity, $\mathrm{NaCl}$. 
(a)
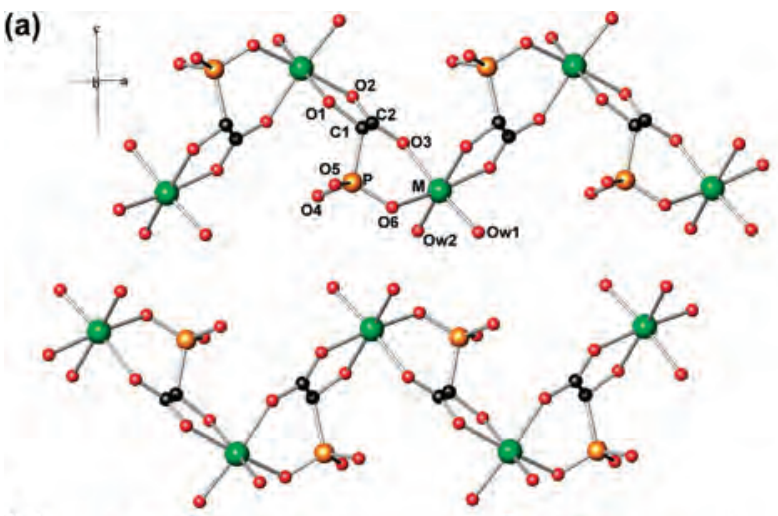

(b)

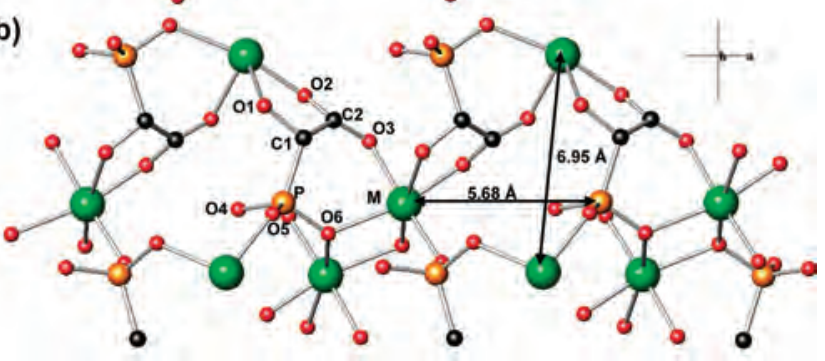

(c)

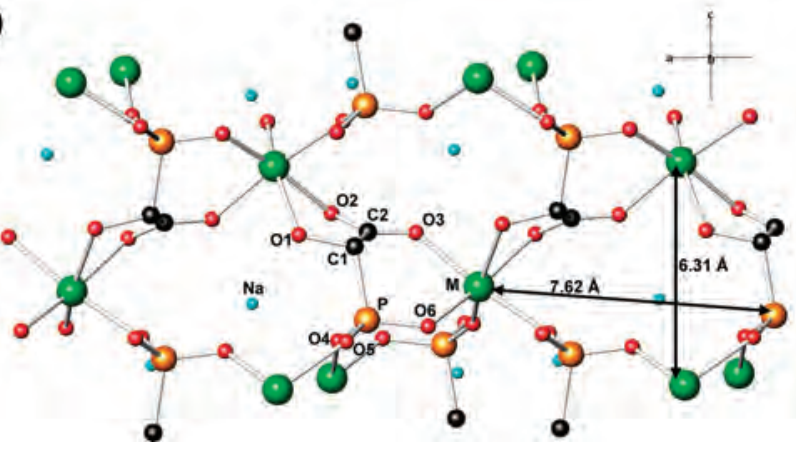

Figure 3. Comparative view of the chains present in the following compounds: (a) $\mathrm{Mg}\left\{\mathrm{HO}_{3} \mathrm{PCH}(\mathrm{OH}) \mathrm{CO}_{2}\right\}\left(\mathrm{H}_{2} \mathrm{O}\right)_{2}$; (b) $\mathrm{Mg}\left\{\mathrm{HO}_{3} \mathrm{PCH}-\right.$ $\left.(\mathrm{OH}) \mathrm{CO}_{2}\right\}$; and (c) $\mathrm{NaMg}\left\{\mathrm{O}_{3} \mathrm{PCH}(\mathrm{OH}) \mathrm{CO}_{2}\right\}$. The chains present in $\left[\mathrm{Mg}\left\{\mathrm{HO}_{3} \mathrm{PCH}(\mathrm{OH}) \mathrm{CO}_{2}\right\}\left(\mathrm{H}_{2} \mathrm{O}\right)_{2}\right] \cdot 2 \mathrm{H}_{2} \mathrm{O}$ are not given as they are almost identical to those present in (a).

with the TG data given above. M-L-2-0-1D, for transition metal compounds, has an orthorhombic symmetry isostructural to Ni-L-2-0-1D ${ }^{8 \mathrm{a}}$ however, $\mathrm{M}=\mathbf{M g}$ shows a slight monoclinic framework distortion, with twice the number of atoms in the asymmetric unit, see Table 2. Intermediate steps of dehydration, at low temperature, gave rise to mixed phase materials containing different proportions of the phases $\mathbf{M}-$ L-2-2-1D and M-L-2-0-1D instead of an intermediate phase with a single water molecule, see for instance the powder pattern of Mg-L-2-2-1D heated at $50{ }^{\circ} \mathrm{C}$ in Figure 2. The phase containing one lattice water molecule, M-L-2-1-1D, has only been isolated as single phase for $\mathrm{M}=\mathrm{Cu}$ and as a mixture for $\mathrm{M}=\mathrm{Ni}$. In a second step of the thermal evolution, the 3D framework M-L-0-0-3D develops, which is very similar to that of $\mathbf{C u}-\mathbf{L}-\mathbf{0 - 0}-\mathbf{0} \mathbf{D}$, obtained by heating of the phase $\mathbf{C u}-\mathbf{L}-\mathbf{2 - 1}-\mathbf{1 D}$ at $170{ }^{\circ} \mathrm{C} .{ }^{8 \mathrm{c}}$ The powder pattern of Mg-L-0-0-3D is already evident at $200{ }^{\circ} \mathrm{C}$ (see Figure 2). On the basis of the above discussion, it appears that this dehydration pattern, from fully hydrated (4 water molecules) to anhydrous frameworks, is a general mechanism for this series of M(II) hybrids.

M-L-2-2-1D ( $\mathrm{M}=\mathrm{Mg}, \mathrm{Co}$, and $\mathrm{Zn})$ have 1D structures crystallizing in orthorhombic cells, see Table 2 and Figure 3.

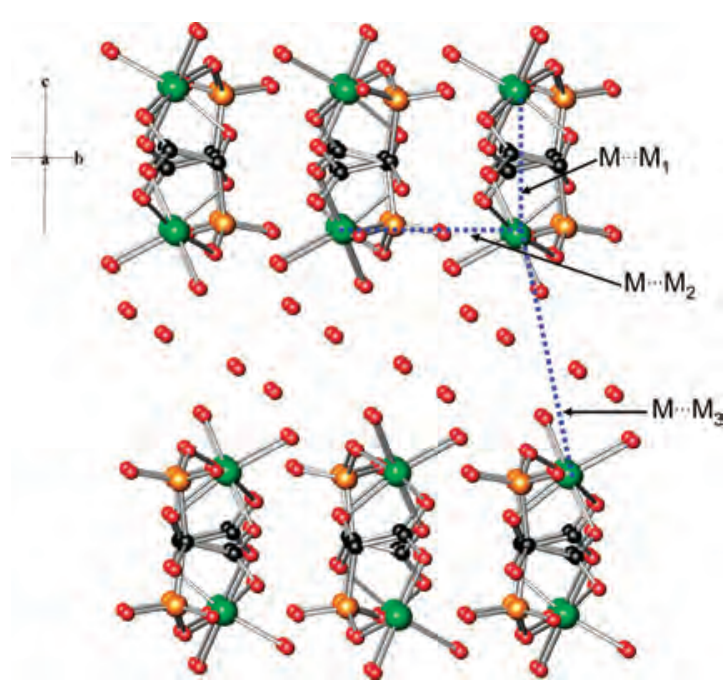

Figure 4. $1 \mathrm{D}$ chain arrangement (viewed down $a$-axis) of $\left[\mathrm{M}\left\{\mathrm{HO}_{3}\right.\right.$ $\left.\left.\mathrm{PCH}(\mathrm{OH}) \mathrm{CO}_{2}\right\}\left(\mathrm{H}_{2} \mathrm{O}\right)_{2}\right] \cdot 2 \mathrm{H}_{2} \mathrm{O}(\mathrm{M}=\mathrm{Mg}, \mathrm{Co}, \mathrm{Zn})$ showing key $\mathrm{M} \cdots \mathrm{M}$ distances for describing the packing.

The crystal structures are quite similar to those already reported for $\mathbf{C u}-\mathbf{L}-\mathbf{2}-\mathbf{1 - 1} \mathbf{D}^{8 \mathrm{~b}}$ and Ni-L-2-0-1D, ${ }^{8 \mathrm{a}}$ but with two interchain water molecules instead of one or none, respectively. The basic building unit of M-L-2-2-1D contains 14 non-hydrogen atoms. The M(II) cations are located in a distorted octahedral environment formed by a chelating bidentate HPAA (phosphonate $\mathrm{O}(6)$ and carboxylate $\mathrm{O}(3)$ ), an monodentate carboxylate, $\mathrm{O}(2)$, a hydroxyl group, $\mathrm{O}(1)$, and two coordination water molecules Ow1 and Ow2 (Figure 3a). Each ligand links two M(II) cations, generating 5- and 6-membered chelate rings, the carboxylate group bridging the two metal centers in a $\eta^{2}-\mu_{2}$-fashion. The resulting infinite chains run parallel to the $a$-axis. A maximum of two lattice water molecules, Ow3 and Ow4, can be hosted between the chains along the $c$-axis (Figure 4). This architecture is further stabilized by a number of $\mathrm{O}-\mathrm{H} \cdots \mathrm{O}$ hydrogen bonds involving the hydroxyl oxygen, carboxylate oxygens, phosphonate oxygen atoms, and coordination and lattices water molecules. The loss of the two intrachain water molecules yields the topotactic conversion of M-L-2-2-1D $(\mathrm{M}=\mathrm{Mg}, \mathrm{Co}$, and $\mathrm{Zn})$ into M-L-2-0-1D $(\mathrm{M}=\mathrm{Mg}, \mathrm{Co}$, and $\mathrm{Zn}$ ). The structures of those compounds are not described in detail as they are isostructural to those already reported for $\mathrm{M}=\mathrm{Cu}^{8 \mathrm{c}}$ and $\mathrm{Ni}^{8 \mathrm{a}}$ Furthermore, loss of the two metalbound water molecules yields M-L-0-0-3D ( $\mathrm{M}=\mathrm{Mg}, \mathrm{Ni}$, $\mathrm{Co}$, and $\mathrm{Zn}$ ), which are isostructural to $\mathbf{C u}-\mathbf{L}-\mathbf{0 - 0}-\mathbf{3 D}{ }^{8 \mathrm{c}}$ Figure $3 \mathrm{~b}$ shows the cross-linking between the coordination polymers after conversion of Mg-L-2-0-1D into Mg-L-0-03D. As already described for $\mathrm{M}=\mathrm{Cu},{ }^{8 \mathrm{c}}$ the zigzag chain in Mg-L-2-2-1D and Mg-L-2-0-1D and the octahedral coordination around the metal ion is retained in the 3D framework, but the connectivity of the phosphonate group with respect to

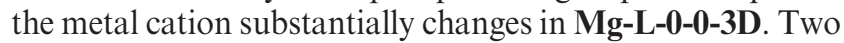
of the three oxygens of the phosphonate group are coordinated to $\mathrm{M}$ (II) centers and one of them, $\mathrm{O}(6)$, links two $\mathrm{M}(\mathrm{II})$ ions, generating edge-sharing $\mathrm{M}_{2} \mathrm{O}_{10}$ dimers. This change in connectivity creates a third 12 -membered ring with representative $\mathrm{M} \cdots \mathrm{P}$ and $\mathrm{M} \cdots \mathrm{M}$ distances of 5.68 and $6.95 \AA$, respectively $\AA$ for Mg-L-0-0-3D (Figure 3b). The refined unit cell parameters of $\mathbf{Z n - L - 0}-\mathbf{0}-\mathbf{1 D}$ are in close agreement with those obtained for $\mathrm{Mg}$ derivative, see Table 3. However, 

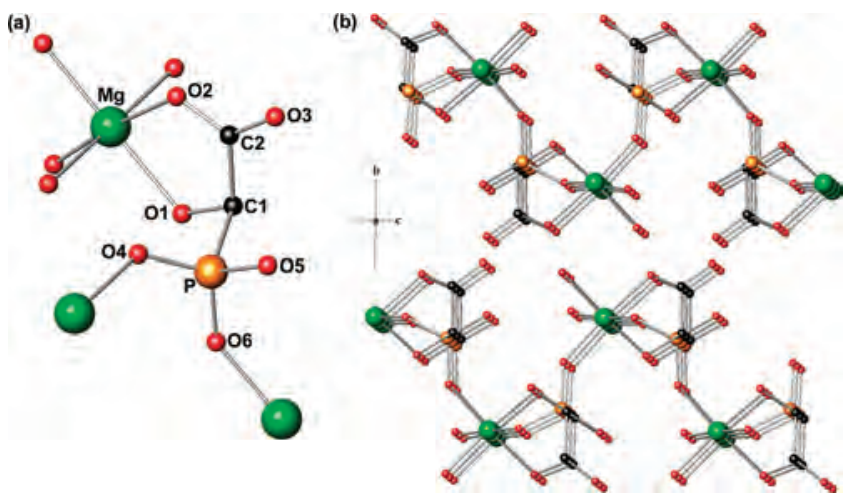

Figure 5. Crystal structure views of $\left[\mathrm{Mg}\left\{\mathrm{HO}_{3} \mathrm{PCH}(\mathrm{OH}) \mathrm{CO}_{2}\right\}\left(\mathrm{H}_{2} \mathrm{O}\right)_{2}\right]$ showing (a) the metal to ligand coordination mode; (b) crystal packing showing the layers along the a axis.

Table 4. Selected Key M $\cdots M$ Distances for Divalent Metal Hydroxyphosphonoacetates Highlighted in Figure 4

\begin{tabular}{llll}
\hline \multicolumn{1}{c}{ phase } & $\begin{array}{c}\text { M } \cdots \mathrm{M}_{1}(\AA) \\
\text { intrachain }\end{array}$ & $\begin{array}{c}\mathrm{M} \cdots \mathrm{M}_{2}(\AA) \\
\text { interchain-short }\end{array}$ & $\begin{array}{c}\mathrm{M} \cdots \mathrm{M}_{3}(\AA) \\
\text { interchain-long }\end{array}$ \\
\hline Mg-L-2-2-1D & 5.88 & 5.27 & 7.47 \\
Mg-L-2-0-1D & 5.97 & 5.42 & 4.91 \\
Mg-L-0-0-3D $_{\text {Zn-L-2-2-1D }}$ & 5.89 & 5.24 & 3.23 \\
Zn-L-2-0-1D $_{\text {Zn- }}$ & 5.90 & 5.27 & 7.44 \\
Cu-L-2-1-1D $^{8 b}$ & 5.77 & 5.36 & 4.98 \\
Cu-L-0-0-3D $^{8 \mathrm{c}}$ & 5.73 & 5.37 & 6.72 \\
Ni-L-2-0-1D $^{8 \mathrm{a}}$ & 5.81 & 5.47 & 3.74 \\
& & 5.34 & 5.04
\end{tabular}

structural data for Zn-L-0-0-3D are not reported because its powder pattern had very broad peaks and the derived structural parameters had very high associated errors.

$\mathrm{M} \cdots \mathrm{M}$ distances (see Figure 4 and Table 4) were measured to follow the structural variations throughout the series. Key distances for the materials prepared in this study, and those derived from structures already reported, are given in Table 4. There are minor changes in the $\mathrm{M} \cdots \mathrm{M}_{1}$ intrachain distance, ranging from $5.77 \AA$ to $5.97 \AA$ for $\mathbf{C u}-\mathbf{L}-\mathbf{0 - 0}-$ 3D and Mg-L-2-0-1D, respectively. Moreover, there are minor changes as well throughout the series in the $\mathrm{M} \cdots \mathrm{M}_{2}$ short interchain distance, along the $b$-axis, during the dehydration processes. The longest and shortest distances are 5.44 and $5.24 \AA$ for $\mathbf{C u}-\mathbf{L}-\mathbf{0 - 0}-\mathbf{0} \mathbf{3}$ and $\mathbf{M g}-\mathbf{L}-\mathbf{0 - 0}-\mathbf{0} \mathbf{3 D}$, respectively. On the other hand, the chain packing along the $c$-axis can be followed by the $\mathrm{M} \cdots \mathrm{M}_{3}$ initially long interchain distance, which profoundly changes with the hydration degree. The longest and shortest distances are 7.47 and $3.23 \AA$ for Mg-L2-2-1D and Mg-L-0-0-3D, respectively.

Hydrothermal reactions at $140-180^{\circ} \mathrm{C}$ lead usually to the formation of layered compounds, M-L-2-0-2D (M = Mn, $\mathrm{Fe}, \mathrm{Co}, \mathrm{Zn}),{ }^{9 \mathrm{a}}$ with the exception of the nickel(II) derivative synthesized at $140^{\circ} \mathrm{C}$. The notation for this framework is NiL-2-0-1D. ${ }^{8 a}$ We have tested this systematic behavior by hydrothermally preparing the previously not reported MgL-2-0-2D at $180^{\circ} \mathrm{C}$. As expected, the resulting compound belongs to that series, ${ }^{9 \mathrm{a}}$ see Table 3 . The crystal structure of Zn-L-2-0-2D was used as starting model for the structural analysis of Mg-L-2-0-2D by the Rietveld method. Figure 5 shows the extended asymmetric unit as well as a view of the packing of the layers for Mg-L-2-0-2D. We do not describe the structure in detail as the series is already known. ${ }^{9 \mathrm{a}}$ The principal distinctive structural feature of the latter compared to the 1D solids is a change in the phosphonate-to-metal connectivity. In this structure the phosphonate group bridges two M(II) ions through two oxygens, while the third oxygen remains uncoordinated. Packing between neighboring layers is realized through hydrogen bonds.

Anionic frameworks with fully deprotonated trianionic HPAA $^{3-}$ have been reported with divalent metal ions. ${ }^{7,9,10}$ In these structures an extra organic or inorganic cation is also incorporated for charge balance. The inclusion of $\mathrm{Na}^{+}$as charge-compensating cation into the anionic framework has led to a series of isomorphous orthorhombic 3D compounds, $\mathrm{NaM}\left\{\mathrm{O}_{3} \mathrm{PCH}(\mathrm{OH}) \mathrm{CO}_{2}\right\}(\mathrm{M}=\mathrm{Mn}, \mathrm{Fe}, \mathrm{Co}, \mathrm{Zn}),{ }^{10} \mathrm{MNa}-\mathrm{L}-$ 0-0-3D, obtained by hydrothermal syntheses. The resulting frameworks incorporate the alkali metal ions as a compensation for the increase in the $\mathrm{M} / \mathrm{P}$ molar ratio and also for the increased $\mathrm{pH}$ above 4.0 (for instance by the presence of an acetate buffer). We have also tested this systematic behavior by preparing hydrothermally the previously not reported MgNa-L-0-0-3D. As expected, the compound was successfully obtained, and its crystal structure determined,

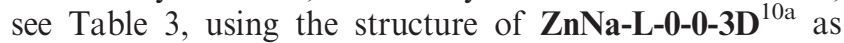
starting model. Figure 1c shows chains present in this family of compounds which are similar to those already described in M-L-0-0-3D. However, the chain connectivity is different from that already described. ${ }^{10 a}$ Each oxygen of the phosphonate group is now coordinated to one $\mathrm{Mg}^{2+}$ ion, but no bridging oxygen atoms are found like in Mg-L-0-0-3D. The edge-sharing $\mathrm{M}_{2} \mathrm{O}_{10}$ dimers are disassembled, and a new 13membered ring in MgNa-L-0-0-3D is created at the expense of the 12-membered one. These structural changes result in a more open framework allowing the incorporation of charge compensating $\mathrm{Na}^{+}$ions. $\mathrm{Mg} \cdots \mathrm{P}$ and $\mathrm{Mg} \cdots \mathrm{Mg}$ distances in the 12- and 13-membered rings in Mg-L-0-0-3D and MgNaL-0-0-3D frameworks are compared in Figure 3. As can be seen, the ring expands along the $a$-axis and shrinks in the $c$ axis. $\mathrm{Na}^{+}$ions are located at the intersections of the channels running along the $a$-axis. ${ }^{10 \mathrm{~b}}$ However, the enlargement of the cavity hosting the alkali metal ions is limited by the rigidity of the bonds established between the polydentate ligand and the octahedral coordinated $\mathrm{M}$ (II) ion. Thus, attempts to crystallize the analogous potassium derivative, MgK-L-0-03D, were unsuccessful, under similar experimental conditions. This behavior is likely due to the steric hindrance to accommodate a cation with larger ionic radius than $\mathrm{Na}^{+}$in such cavities.

Finally, $\left(\mathrm{NH}_{4}\right) \mathrm{Zn}\left\{\mathrm{O}_{3} \mathrm{PCH}(\mathrm{OH}) \mathrm{CO}_{2}\right\}$ is already known and its synthesis was carried out under hydrothermal conditions. ${ }^{7}$ As MgK-L-0-0-3D could not be prepared, see above, we tested the possibility of obtaining ZnK-L-0-0-3D by using similar conditions to those already reported for $\mathbf{Z n N H}_{\mathbf{4}}-\mathbf{L}-\mathbf{- 0}-$ 0-3D. ${ }^{7}$ As expected, ZnK-L-0-0-3D was prepared and its crystal structure determined by the Rietveld method using that of $\mathbf{Z n N H}_{4}-\mathbf{L}-\mathbf{0 - 0 - 3 D}$ as starting model. It must be noted that the crystal structures of these compounds are different from those already described for MNa-L-0-0-3D $(\mathbf{M}=\mathbf{M g}$, $\mathrm{Mn}, \mathrm{Fe}, \mathrm{Co}, \mathrm{Zn}$ ). The most significant structural feature in ZnK-L-0-0-3D is the tetrahedral coordination around the $\mathrm{Zn}^{2+}$ cations. This structure possesses interconnected 24-, 16-, and 8-atom channels and high thermal stability (Figure 6). ${ }^{7}$ Another distinctive structural feature of the $3 \mathrm{D} \mathrm{Zn}^{2+}$ derivatives is that the hydroxyl group no longer interacts with the divalent cation generating a more open $3 \mathrm{D}$ framework able to host bigger alkali cations. It is worth noting that 


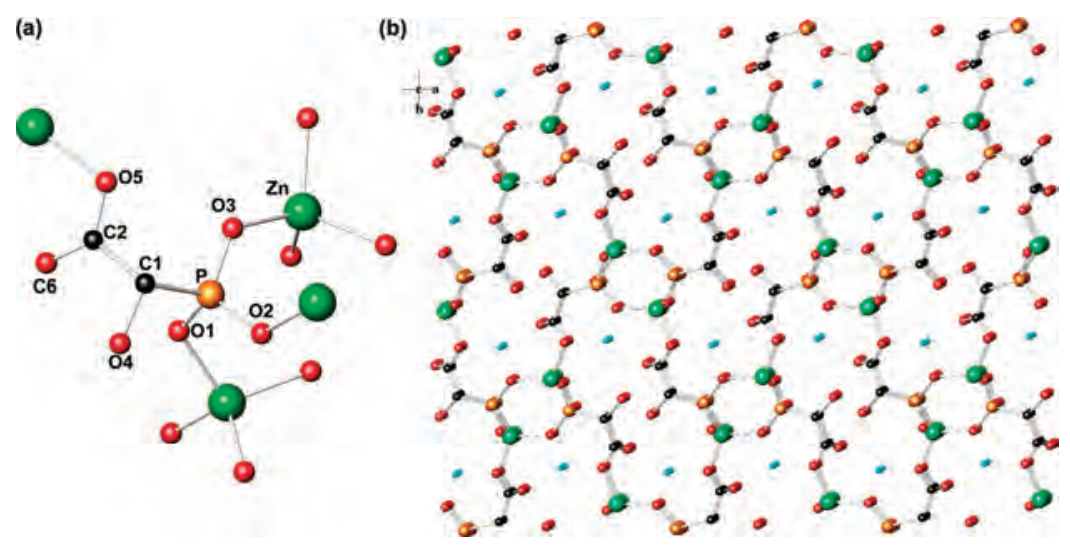

Figure 6. Crystal structure views of $\left[\mathrm{KZn}\left\{\mathrm{O}_{3} \mathrm{PCH}(\mathrm{OH}) \mathrm{CO}_{2}\right\}\right]$ showing (a) the metal to ligand coordination mode; (b) the $3 \mathrm{D}$ crystal packing showing the $\mathrm{K}^{+}$ions filling the channels.

$\mathrm{NaZn}\left\{\mathrm{O}_{3} \mathrm{PCH}(\mathrm{OH}) \mathrm{CO}_{2}\right\}^{10 \mathrm{a}}$ and $\mathrm{KZn}\left\{\mathrm{O}_{3} \mathrm{PCH}(\mathrm{OH}) \mathrm{CO}_{2}\right\}$ are not isostructural and that the variable coordination of $\mathrm{Zn}(\mathrm{II})$ in these frameworks seems to permit the incorporation of alkali ions with variable sizes. Thus, when $\mathrm{Zn}$ (II) exhibits an octahedral coordination, a more compact framework is obtained which can only accommodate small cations like $\mathrm{Na}^{+}$. Conversely, the presence of $\mathrm{Zn}^{2+}$ cations in tetrahedral oxygen environment leads to a more open framework that can accommodate larger cations, such as $\mathrm{K}^{+}$.

\section{Conclusions}

A comprehensive study of M(II) hydroxyphosphonoacetate hybrids is reported. A new stoichiometry, $\left[\mathrm{M}\left\{\mathrm{HO}_{3} \mathrm{PCH}-\right.\right.$ $\left.\left.(\mathrm{OH}) \mathrm{CO}_{2}\right\}\left(\mathrm{H}_{2} \mathrm{O}\right)_{2}\right] \cdot 2 \mathrm{H}_{2} \mathrm{O}(\mathrm{M}=\mathrm{Mg}, \mathrm{Co}$, and $\mathrm{Zn})$ is reported with $1 \mathrm{D}$ structure similar to that already published for $\left[\mathrm{Cu}\left\{\mathrm{HO}_{3} \mathrm{PCH}(\mathrm{OH}) \mathrm{CO}_{2}\right\}\left(\mathrm{H}_{2} \mathrm{O}\right)_{2}\right] \cdot \mathrm{H}_{2} \mathrm{O}$. ${ }^{8 b}$ The thermal evolution of these phases to yield $1 \mathrm{D}$ compounds without the lattice water, $\left[\mathrm{M}\left\{\mathrm{HO}_{3} \mathrm{PCH}(\mathrm{OH}) \mathrm{CO}_{2}\right\}\left(\mathrm{H}_{2} \mathrm{O}\right)_{2}\right](\mathrm{M}=\mathrm{Mg}, \mathrm{Co}$, and $\mathrm{Zn}$ ), was studied by thermal analysis and thermodiffractometry. The topotactic transformation to a $3 \mathrm{D}$ structure of composition $\mathrm{M}\left\{\mathrm{HO}_{3} \mathrm{PCH}(\mathrm{OH}) \mathrm{CO}_{2}\right\}(\mathrm{M}=\mathrm{Mg}, \mathrm{Co}, \mathrm{Ni}, \mathrm{Cu}$, and $\mathrm{Zn}$ ) is also reported being a general mechanism within this family of compounds. Although there are several possible structures in the M(II)-HPAA system, because of the variability in the hydration degree and the dimensionality of the frameworks, three additional hybrids were prepared having the expected stoichiometries and crystal structures. Layered $\left[\mathrm{Mg}\left\{\mathrm{HO}_{3} \mathrm{PCH}(\mathrm{OH}) \mathrm{CO}_{2}\right\}\left(\mathrm{H}_{2} \mathrm{O}\right)_{2}\right]$ was hydrothermally prepared under the same experimental conditions under which layered $\left[\mathrm{Zn}\left\{\mathrm{HO}_{3} \mathrm{PCH}(\mathrm{OH}) \mathrm{CO}_{2}\right\}\left(\mathrm{H}_{2} \mathrm{O}\right)_{2}\right]$ was already reported to crystallize. Furthermore, $\mathrm{NaMg}\left\{\mathrm{O}_{3} \mathrm{PCH}(\mathrm{OH}) \mathrm{CO}_{2}\right\}$ and $\mathrm{KZn}\left\{\mathrm{O}_{3} \mathrm{PCH}(\mathrm{OH}) \mathrm{CO}_{2}\right\}$ hybrids have been isolated. Both possess $3 \mathrm{D}$ structures, but are not isostructural. It is worth noting that $\mathrm{AZn}\left\{\mathrm{O}_{3} \mathrm{PCH}(\mathrm{OH}) \mathrm{CO}_{2}\right\} \quad(\mathrm{A}=\mathrm{Na}, \mathrm{K})$ have different structures with the $\mathrm{Zn}$ environment being octahedral for $\mathrm{A}=\mathrm{Na}$ and tetrahedral for $\mathrm{A}=\mathrm{K}$. This change in the oxygen environment around the $\mathrm{Zn}(\mathrm{II})$ cations allows the construction of two different frameworks that have appropriate voids to accommodate alkali metal cations of different sizes.

Acknowledgment. The work at UMA was funded by MAT2006-11080-C02-01 research grant. The work at UOC was funded by the Special Research Account (ELKE), project KA 2573.

Supporting Information Available: Cif files for all new structures. The CCDC reference numbers are given in Table 2. X-ray powder diffraction Rietveld plots for: $\mathbf{S 1}\left[\mathrm{Mg}\left\{\mathrm{HO}_{3} \mathrm{PCH}(\mathrm{OH})\right.\right.$ $\left.\left.\mathrm{CO}_{2}\right\}\left(\mathrm{H}_{2} \mathrm{O}\right)_{2}\right] \cdot 2 \mathrm{H}_{2} \mathrm{O}$ (Mg-L-2-2-1D); $\mathbf{S 2}\left[\mathrm{Mg}\left\{\mathrm{HO}_{3} \mathrm{PCH}(\mathrm{OH})-\right.\right.$ $\left.\left.\mathrm{CO}_{2}\right\}\left(\mathrm{H}_{2} \mathrm{O}\right)_{2}\right]$ (Mg-L-2-0-1D); $\mathbf{S 3} \mathrm{Mg}\left\{\mathrm{HO}_{3} \mathrm{PCH}(\mathrm{OH}) \mathrm{CO}_{2}\right\}$ (MgL-0-0-3D); S4 [Mg $\left.\left\{\mathrm{HO}_{3} \mathrm{PCH}(\mathrm{OH}) \mathrm{CO}_{2}\right\}\left(\mathrm{H}_{2} \mathrm{O}\right)_{2}\right]$ (Mg-L-2-0-2D); S5 $\mathrm{NaMg}\left\{\mathrm{O}_{3} \mathrm{PCH}(\mathrm{OH}) \mathrm{CO}_{2}\right\}$ (MgNa-L-0-0-3D); S6 $\left[\mathrm{Zn}\left\{\mathrm{HO}_{3}\right.\right.$ $\left.\left.\mathrm{PCH}(\mathrm{OH}) \mathrm{CO}_{2}\right\}\left(\mathrm{H}_{2} \mathrm{O}\right)_{2}\right] \cdot 2 \mathrm{H}_{2} \mathrm{O}(\mathbf{Z n - L}-2-2-1 D)$; $\mathbf{S} 7\left[\mathrm{Zn}\left\{\mathrm{HO}_{3} \mathrm{PCH}-\right.\right.$ $\left.\left.(\mathrm{OH}) \mathrm{CO}_{2}\right\}\left(\mathrm{H}_{2} \mathrm{O}\right)_{2}\right]$ (Zn-L-2-0-1D); $\mathbf{S 8} \quad \mathrm{KZn}\left\{\mathrm{O}_{3} \mathrm{PCH}(\mathrm{OH}) \mathrm{CO}_{2}\right\}$ (ZnK-L-0-0-3D); S9 mixture of $\left[\mathrm{Ni}\left\{\mathrm{HO}_{3} \mathrm{PCH}(\mathrm{OH}) \mathrm{CO}_{2}\right\}\left(\mathrm{H}_{2^{-}}\right.\right.$ $\left.\mathrm{O})_{2}\right] \cdot \mathrm{H}_{2} \mathrm{O}$ (Ni-L-2-1-1D) and $\left[\mathrm{Ni}\left\{\mathrm{HO}_{3} \mathrm{PCH}(\mathrm{OH}) \mathrm{CO}_{2}\right\}\left(\mathrm{H}_{2} \mathrm{O}\right)_{2}\right]$ (Ni-L-2-0-1D); $\mathbf{S 1 0}\left[\mathrm{Co}\left\{\mathrm{HO}_{3} \mathrm{PCH}(\mathrm{OH}) \mathrm{CO}_{2}\right\}\left(\mathrm{H}_{2} \mathrm{O}\right)_{2}\right] \cdot 2 \mathrm{H}_{2} \mathrm{O}(\mathbf{C o}-$ L-2-2-1D); and S11 [ $\left.\mathrm{Co}\left\{\mathrm{HO}_{3} \mathrm{PCH}(\mathrm{OH}) \mathrm{CO}_{2}\right\}\left(\mathrm{H}_{2} \mathrm{O}\right)_{2}\right]$ Co-L-2-01D). This material is available free of charge via the Internet at http://pubs.acs.org. 